ABDIMAS: Jurnal Pengabdian Masyarakat Universitas Merdeka Malang
Vol.6(1) February 2021, 114-120
U-ISSN: 2721-138x e-ISSN: 2548-7159
Uttp://jurnal.unmer.ac.id/index.php/jpkm

\title{
Pemanfaatan Diversifikasi Olahan Jagung untuk Meningkatkan Gizi dan Pendapatan Masyarakat Desa Bohulo Kabupaten Gorontalo Utara
}

\author{
Arafik Lamadi ${ }^{1}$, Sutianto Pratama Suherman'1, Wila Rumina Nento ${ }^{2}$ \\ ${ }^{1}$ Departemen Budidaya Perairan, ${ }^{2}$ Departemen Teknologi Hasil Perikanan \\ Fakultas Perikanan dan Ilmu Kelautan, Universitas Negeri Gorontalo \\ Jl. Jenderal Sudirman No.6 Gorontalo, 96128, Indonesia
}

\begin{abstract}
ARTICLE INFO
Received: $2020-10-10$

Revised: 2020-12-02

Accepted: 2021-01-18

Keywords:

Brownies, Community empowerment, Corn, Economic value, Farmers
\end{abstract}

\section{ABSTRACT}

Bohulo Village, North Gorontalo District, is mostly agricultural land planted with rice and maize. The abundant maize yields in the area have not been followed by maximum utilization. The problem is, the farmers' ability to sell their crops is limited. Therefore, it is necessary to increase the use of crops, especially corn, into processed products that can increase community income, namely in the form of corn brownies. The purpose of this community empowerment program is technology transfer to increase the economic value of corn. This approach method is a participatory method consisting of site surveys, training and evaluation. This activity shows the enthusiasm of the community, especially the women in Family Welfare Education or PKK, corn farmers, and community leaders in Bohulo Village. Corn that is processed into various kinds of food not only adds attractiveness but also provides opportunities to increase income so that it can improve community welfare. In the future, corn-based food processing can be developed into various products due to the availability of raw materials.

(C) 2021 Published by University of Merdeka Malang. This is an open access article distributed under the CC BY-SA 4.0 license (https://creativecommons.org/licenses/by-sa/4.0/)

How to cite: Lamadi, A., Suherman, S. P., \& Nento, W. R. (2021). Pemanfaatan Diversifikasi Olahan Jagung untuk Meningkatkan Gizi dan Pendapatan Masyarakat Desa Bohulo Kabupaten Gorontalo Utara. Abdimas: Jurnal Pengabdian Masyarakat Universitas Merdeka Malang, 6(1), 114-120. https://doi.org/10.26905/abdimas.v6i1.4920

\section{PENDAHULUAN}

Desa Bohulo adalah desa yang terletak di Kecamatan Biau, Kabupaten Gorontalo Utara, Provinsi Gorontalo. Masyarakat Desa Bohulo sebagian besar mata pencaharian adalah petani. Sebagiannya lagi terbagi pada pekerjaan Pegawai Negeri Sipil (PNS), pedagang, supir, dan tukang. Sekitar $80 \%$ lahannya ditanami padi dan jagung. Jagung merupakan salah satu komoditas hasil panen dari masyarakat Desa Bohulo. Pemanfaatan hasil jagung masyarakat Desa Bohulo sepanjang diamati hanya sebatas makanan primer seperti penganti beras dan dijual dalam bentuk bahan mentah seperti pakan. Berdasarkan hasil survey, masyarakat Desa Bohulo ini memiliki permasalahan dalam pemanfaatan jagung sebagai produk yang mampu menambah nilai produksi, serta meningkatkan pendapatan masyarakat. Hal ini dapat 
dilihat dari rendahnya pendapatan per kapita warga Desa Bohulo. Dari hasil wawancara dengan aparat desa sebagian besar pendapatan masyarakat berada dibawah 1 juta rupiah, padahal jika dikelola dengan baik jagung dapat dijadikan olahan yang memilki nilai ekonomis contohnya keripik, es krim, dan masih banyak lagi produk olahan yang berbahan dasar jagung. Jagung memiliki beberapa kandungan gizi seperti terlihat pada Tabel 1.

Tabel 1. Kandungan per 100 gram dari jagung

\begin{tabular}{lr}
\hline \multicolumn{1}{c}{ Kandungan } & Jumlah \\
\hline Kalori & 355 Kalori \\
Protein & $9,2 \mathrm{gr}$ \\
Lemak & $3,9 \mathrm{gr}$ \\
Karbohidrat & $73,7 \mathrm{gr}$ \\
Kalsium & $10 \mathrm{mg}$ \\
Fosfor & $256 \mathrm{mg}$ \\
Ferrum & $2,4 \mathrm{mg}$ \\
Vitamin A & $510 \mathrm{SI}$ \\
Vitamin B & $0,38 \mathrm{mg}$ \\
Asam Folat & $12 \%$ \\
Air & $12 \mathrm{gr}$ \\
\hline Sumber: Sudarmaii (2003)
\end{tabular}

Sumber: Sudarmaji (2003)

Penelitian Boyer \& Shannon (2003) juga menemukan adanya komponen kimia terbesar yang ada pada jagung adalah karbohidrat (72\% dari berat biji) yang sebagian besar terdapat pada bagian endosperma. Endosperma matang mengandung $86 \%$ pati dan gula sekitar $1 \%$. Ditambah juga biji jagung terdiri dari beberapa jenis vitamin seperti niasin (28 mg/kg), kolin (567 mg/kg), piridoksin (5,3 $\mathrm{mg} / \mathrm{kg}$ ), tiamin $(3,8 \mathrm{mg} / \mathrm{kg})$, asam pantotenat $(6,6 \mathrm{mg} / \mathrm{kg})$, asam folat $(0,3 \mathrm{mg} / \mathrm{kg})$, riboflavin $(1,4 \mathrm{mg} / \mathrm{kg})$, biotin $(0,08 \mathrm{mg} / \mathrm{kg}$ ), serta vitamin A (karoten) sebesar $2,5 \mathrm{mg} / \mathrm{kg}$ dan vitamin $\mathrm{E}$ (tokoferol) $30 \mathrm{IU} / \mathrm{kg}$.

Retno (2009) mengamati spesies jagung yang selama ini berada di Indonesia. Ternyata dari hasil pengamatanya di Indonesia terdapat 2 (dua) varietas jagung yang telah ditanam oleh masyarakat umum, yakni jagung berwarna kuning dan putih. Kedua varietas tersebut memiliki kandungan karbohidrat yang sangat tinggi. Karbohidrat yang paling tinggi terdapat pada bagian endospermium. Menurut Suarni (2009) Kandungan karbohidrat dapat mencapai $80 \%$ dari seluruh bahan kering biji. Karbohidrat dalam bentuk patin umumnya berupa campuran amilosa dan amilopektin. Pada jagung ketan, sebagian besar atau seluruh patin yang merupakan amilopektin.

Berdasarkan kandungan gizi tersebut sangat mungkin pembuatan brownies berbahan jagung sebagai upaya peningkatan ekonomi masyarakat, mengingat brownies adalah suatu cake atau makanan yang disukai oleh kalangan anak-anak, dewasa sampai orang tua (Astawan, 2009). Hal ini terbukti dari banyaknya outlet yang menjual brownies dengan berbagai macam rasa ditambah lagi café-café yang menyediakan brownies pada menu makanan. Produk ini diharapkan mampu menjadikan salah satu faktor penggerak ekonomi masyarakat terutama untuk UKM yang ada di Desa Bohulo.

Perkembangan produk olahan jagung sudah banyak disosialisaikan dalam beberapa pengabdian seperti pengolahan jagung menjadi emping coklat di Desa Arjasari Kabupaten Bandung (Djali, 2018), 
ABDIMAS: Jurnal Pengabdian Masyarakat Universitas Merdeka Malang Volume 6, No. 1, February 2021: 114-120

pengolahan jagung menjadi mie, susu dan tempe jagung di Labuapi Kabupaten Lombok Barat (Maherawati \& Sarbino, 2018; Kurniasih \& Dewi, 2017) dan pengolahan jagung menjadi dodol di Kecamatan Paiton, Kabupaten Probolinggo (Novia et al., 2017), serta pengolahan sebagai diversifikasi produk dalam rangka meningkat nilai tukar petani (Suwardi et al., 2019).

Kegiatan ini bertujuan untuk memberikan pelatihan dan pendampingan kepada masyarakat untuk meningkatkan produk olahan berbahan dasar jagung sehingga dapat meningkatkan nilai tambah produk jagung tersebut.

\section{METODE}

Pengabdian ini menggunakan metode pendekatan partisipatif untuk mendapatkan tujuan dan outcome yang diharapkan. Adapun metode yang dilakukan pada kegiatan ini disajikan dalam Gambar 1.

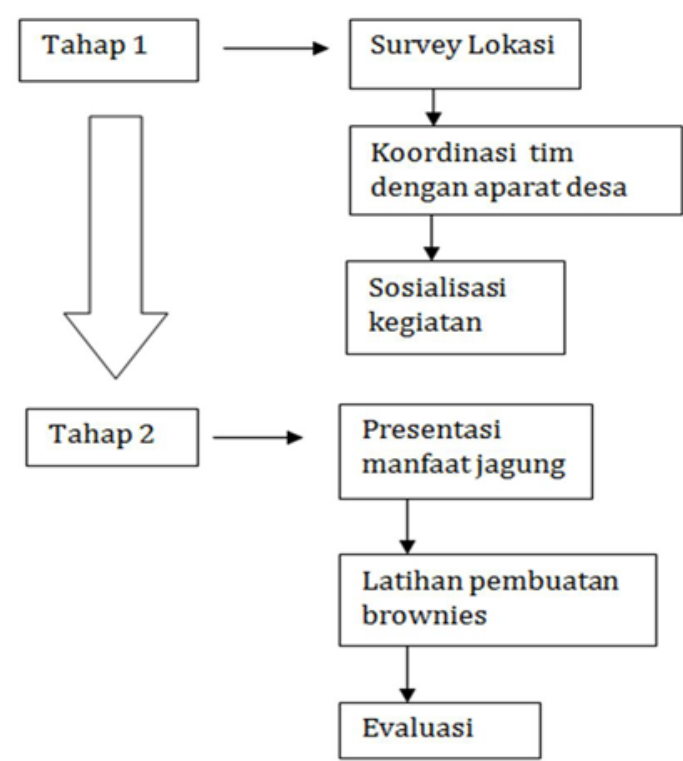

Gambar 1. Alur pelaksanaan pengabdian masyarakat Desa Bohulo, Kecamatan Biau

\section{Tahap Pertama}

Tahapan pertama yaitu survey lokasi bertujuan untuk melihat langsung keadaan lokasi, khususnya lahan pertanian yang ditanami jagung, serta melakukan sosialisasi kepada masyarakat bahwa akan dilaksanakan seminar mengenai diversifikasi produk yang berbahan jagung. Dari hasil pengamatan citra satelit (Gambar 2), Desa Bohulo dikelilingi oleh 12 desa yakni Desa Potangan, Tolitejaya, Tolinggula Tengah, Molangga, Omuto, Bualo, Didingga, Sembihingan, Leato Tumba, Pangahu, Botumoito, Hutamonu dan Dungalea. Selain itu penampakan desa sebagian besar dikelilingi oleh hutan alami. 


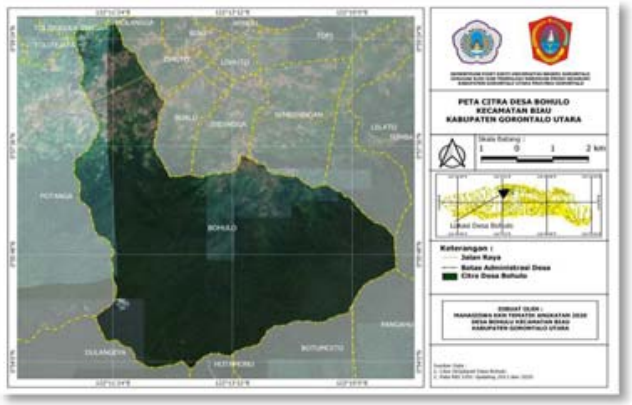

Gambar 2. Peta citra Desa Bohulo

\section{Tahapan Kedua}

Pada tahap ini hal yang pertama kali yang dilakukan adalah seminar dengan teknik ceramah mengenai pontesi dan manfaat jagung bagi ekonomi dan kesahatan. Setelah itu pelatihan pembuatan brownies jagung yang disertai dengan pendampingan langsung selama proses pembuatan.

Ada beberapa tahapan yang akan dilaksanakan. Pelaksanaan kegiatan pengabdian dilakukan dalam lima tahap yakni: (1) Penjelasan secara teori tentang potensi jagung; (2) Praktek pembuatan brownies jagung; (3) Analisis organoletik untuk mengetahui tingkat kesukaan masyarakat terhadap brownies jagung; (4) Pelatihan pengemasan produk yang baik dan benar; dan (5) Pelatihan manajemen usaha dan pemasaran. Pelaksanaan kegiatan dilaksanakan secara bertahap dengan maksud agar proses alih ilmu pengetahuan dan teknologi dari tim pengabdi UNG kepada masyarakat lebih gampang dan mudah dipahami.

\section{HASIL DAN PEMBAHASAN}

\section{Survei Lapangan dan Potensi Desa}

Desa Bohulo adalah salah satu Desa yang berada di Kecamatan Biau, Kabupaten Gorontalo Utara, Provinsi Gorontalo. Jarak desa ini dari kampus Universitas Negeri Gorontalo adalah sekitar 164 km. Desa Bohulo merupakan desa penghasil jagung terbesar di Kabupaten Gorontalo Utara. Potensi jagung di desa ini terhitung cukup besar dan dapat dimanfaatkan oleh masyarakat desa untuk membentuk lapangan kerja baru yang dapat menyokong roda perekonomian desa khususnya dalam meningkatkan pendapatan masyarakatnya.
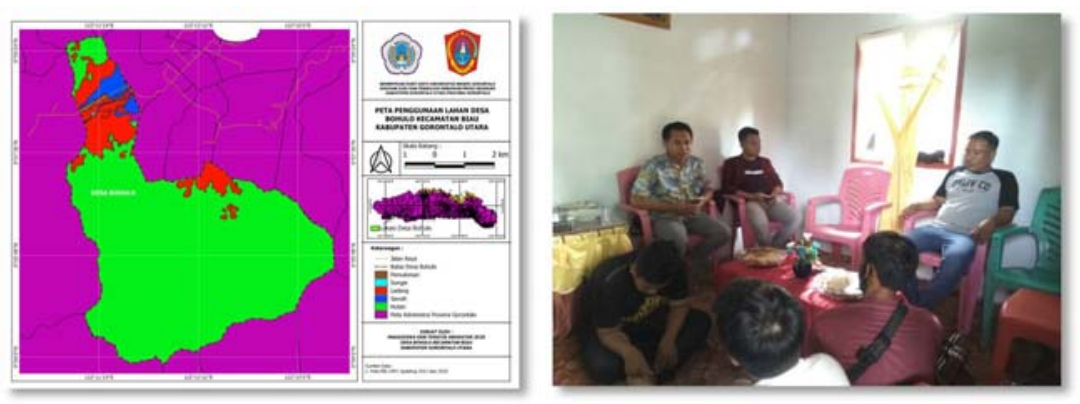

Gambar 3. Peta penggunaan lahan desa

Gambar 4. Koordinasi tim pengabdian dengan Kepala Desa Bohulo 
ABDIMAS: Jurnal Pengabdian Masyarakat Universitas Merdeka Malang

Volume 6, No. 1, February 2021: 114-120

Dari hasil survey yang dilakukan Desa Bohulo memiliki luas lahan pertanian +20 hektar yang $60 \%$ ditanami oleh tanaman jagung, kondisi wilayah tersebut dapat diamati pada Gambar 3 tepatnya pada warna merah. Selanjutnya melakukan koordinasi dengan Kepala Desa Bohulo terkait kegiatan pengabdian yang akan dilakukan. Dari hasil pertemuan tersebut mendapat sambutan yang baik dari kepala desa. Hal ini terbukti dari mudahnya pengurusan perizinan yang diberikan.

Perizinan yang diberikan berupa penyediaan waktu dan tempat, serta kesediaan aparat desa untuk menghadirkan masyarakat yang akan hadir pada pelatihan pembuatan brownies jagung. Pelatihan ini akan dilaksanakan di halaman Kantor Desa Bohulo pada tanggal 15 September 2020.

\section{Pelaksanaan Pelatihan dan Teori Penyuluhan}

Kegiatan ini dilaksanakan pada tanggal 15 September 2020 bertempat di halaman Kantor Desa Bohulo Kecamatan Biau dengan jumlah peserta 40 orang yang terdiri dari ibu-ibu PKK dan Kader setiap RW. Bentuk dari kegiatan ini berupa sambutan dari Kepala Desa dan pemaparan materi pelatihan oleh tim DPL yang meliputi: (1) Pengetahuan tentang jagung; (2) Cara pengolahan jagung yang baik (GMP); (3) Pembuatan brownies; dan (4) Teknologi Pengemasan. Setelah pemaparan materi ibu-ibu mempraktekkan langsung cara pembuatan brownies jagung yang diwakili oleh ketua PKK beserta tim dengan didampingi oleh Dosen Pembimbing Lapangan dan dua orang mahasiswa. Pembuatan brownies ini diawali dengan pengenalan alat dan bahan sampai pada tahap pengukusan. Hasil dari praktek ini akan dipantau dan dievaluasi oleh tim pengabdian. Dengan kegiatan ini diharapkan masyarakat dapat meningkatkan pendapatan dari pengolahan produk berbahan jagung.
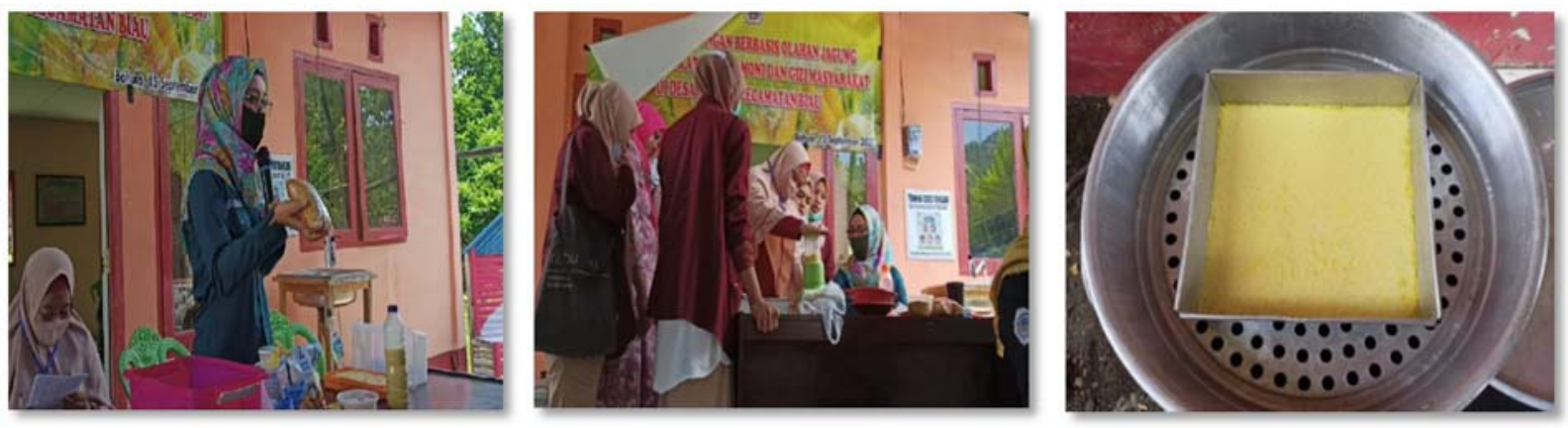

Gambar 5. Pengenalan alat dan bahan, praktek pembuatan brownies oleh ibu-ibu PKK, dan brownies jagung

\section{Evaluasi Produksi Brownies}

Pemantauan dilaksanakan oleh tim DPL dan mahasiswa terhadap proses pembuatan brownies jagung pada tanggal 17 September 2020. Aktifnya masyarakat dalam menanggapi materi pelatihan dalam pembuatan brownies jagung tersebut ditandai dengan antusiasnya masyakarat yang berlombalomba dalam mempraktekkan pembuatan brownies ini. Di samping itu, rasa dan tekstur yang dihasilkan dari pembuatan produk brownies ini sangat baik dan beda dengan produk brownies pada umumnya yang menambah semangat masyarakat Desa Bohulo untuk menjadkan produk brownies jagung sebagai salah satu icon dari masyarakat Desa Bohulo. 


\section{SIMPULAN DAN SARAN}

\section{Simpulan}

Kegiatan ini merupakan bentuk pengabdian masyarakat yang dilaksanakan oleh Universitas Gorontalo. Selama kegiatan berlangsung ibu-ibu dan masyarakat Desa Bohulo menyambut baik Tim DPL dan Mahasiswa, diharapkan kedepannya brownies jagung ini dinilai memilki prospek yang bagus untuk pendapatan masyarakat kerena ditunjang oleh ketersediaan bahan baku. Meskipun demikian berbagai manfaat yang dapat dirasakan oleh peserta pengabdian antara lain: (1) Timbulnya sikap peduli, empati mahasiswa terhadap kendala-kendala sosial yang ada dimasyarakat pada umumnya khususnya di Desa Bohulo. Disamping itu pula mahasiswa dapat mengaplikasikan teori beserta praktek dari berbagai disiplin ilmu; (2) Pemerintah setempat dalam hal ini Kepala Desa Bohulo telah terbantu dalam meningkatkan pemberdayaan masyarakat, khususnya petani jagung; (3) Sebagai kontribusi perguruan tinggi dan tim dosen dalam hal menjawab masalah yang dihadapi oleh kelompok sasaran, dlam hal ini masayarakat desa Bohulo.

\section{Saran}

Kegiatan ini bertujuan untuk mengetahui kendala-kendala yang dihadapi masyarakat selama proses produksi. Ada beberapa kendala yang dihadapi oleh masyarakat Desa Bohulo di antaranya sulitnya mendapatkan bahan baku berupa keju dan peningkatan penjualan melalui cara pemasaran yang optimal, sebab letak desa yang agak jauh dari sarana trasportasi umum. Untuk itu beberapa masukan yang diberikan oleh tim pelaksana antara lain: (1) Perlu diadakan lagi lanjutan pengabdian dari kegiatan ini khususnya berhubungan dengan kendala pemasaran produk ini. Dengan memberikan beberapa alternatif pemasaran yang diharapkan dapat meningkatkan penjualan; (2) Perlu adanya pengembangan kegiatan ini melalui Program Kemitraan Wilayah (PKW) untuk menguatkan potensi jagung menjadi berbagai olahan pangan.

\section{Ucapan Terima Kasih}

Penulis mengucapkan terima kasih kepada Rektor Universitas Negeri Gorontalo, Dr. Eduart Wolok, S.T, M.T, LPPM Universitas Negeri Gorontalo, Pemerintah Kabupaten Gorontalo Utara, Kepala Desa Bohulo Serta masyarakat Desa Bohulo, Mahasiswa yang berperan mendukung pelaksanaan kegiatan ini.

\section{DAFTAR PUSTAKA}

Astawan, M. (2009). Ensiklopedia Gizi Pangan. Jakarta: Dian Rakyat.

Boyer, C. D., \& Shannon, J. C. (2003). Carbohydrates of the Kernel. Minnesota: American Association of Cereal Chemistry Inc.

Djali, M. (2018). Teknologi pengolahan Emping Jubika sebagai upaya peningkatan nilai guna jagung manis di Desa Arjasari Kabupaten Bandung. Jurnal Pengabdian Kepada Masyarakat, 2(1), 1922. 
ABDIMAS: Jurnal Pengabdian Masyarakat Universitas Merdeka Malang Volume 6, No. 1, February 2021: 114-120

Kurniasih, Y., \& Dewi, C. A. (2017). Pemberdayaan petani jagung melalui pengembangan usaha diversifikasi produk olahan jagung di Labuapi Kabupaten Lombok Barat. Jurnal Pengabdian Kepada Masyarakat IKIP Mataram, 2(1), 1-6. https://doi.org/10.24843/BUM.2019.v18.i03.p08

Maherawati, M., \& Sarbino, S. (2018). Diversifikasi produk olahan jagung manis sebagai upaya peningkatan nilai tambah bagi petani jagung di daerah Wisata Pasir Panjang-Singkawang. Jurnal Pengabdi, 1(1), 17. https://doi.org/10.26418/jplp2km.v1i1.25477

Novia, C., Syaiful, S., \& Utomo, D. (2017). Kreatifitas masyarakat dalam diversifikasi olahan jagung serta pemanfaatan media sosial sebagai sarana promosi produk. Jurnal Teknologi Pangan, 8(2), 132-136. https://doi.org/10.35891/tp.v8i2.642

Retno, A. (2009). Pelatihan Teknologi Olahan Bahan Pangan dari Bahan Dasar Jagung sebagai Alternatif Wirausaha bagi Masyarakat Kurang Mampu di Dusun Gembyong, Ngoro-Oro, Kecamatan Patuk, Kabupaten Gunung Kidul. Yogyakarta: LPPMP UNY.

Suarni, S. (2009). Prospek pemanfaatan tepung jagung untuk kue kering (cookies). Jurnal Litbang Pertanian, 28(2), 63-71. http://dx.doi.org/10.21082/jp3.v28n2.2009.p63\%20-\%2071

Sudarmaji, S. (2003). Analisa Bahan Makanan dan Pertanian. Yogyakarta: Kanisius.

Suwardi, D., Saputri, D. S., \& Permatacita, F. (2019). Pemberdayaan petani Jagung Orba (Orong Bawa) melalui pengembangan usaha diversifikasi produk olahan jagung sebagai upaya meningkatkan nilai tukar petani. Jurnal TAMBORA, 3(1), 64-68. http://dx.doi.org/10.36761/jt.v3i1.187 